\title{
PEMANFAATAN LIMBAH CAIR PRODUKSI ALKALI TREATED SARGASSUM SEBAGAI BAHAN BAKU PUPUK CAIR
}

\section{Utilization of Liquid Waste from Alkali Treated Sargassum Processing as a Raw Material for Liquid Fertilizer}

\author{
Jamal Basmal ${ }^{1 *}$, Vina Asfia Chori ${ }^{2}$, dan Nurhayati ${ }^{1}$ \\ ${ }^{1}$ Balai Besar Riset Pengolahan Produk dan Bioteknologi Kelautan dan Perikanan, \\ JI. KS Tubun Petamburan VI, Slipi, Jakarta, Indonesia \\ ${ }^{2}$ Universitas Brawijaya, Jalan Veteran, Ketawanggede, Malang, Jawa Timur \\ * Korespondensi Penulis: jamalbasmal24@gmail.com
}

Diterima: 21 Juni 2016; Direvisi: 6 Juli 2017; Disetujui: 25 Agustus 2017

\begin{abstract}
ABSTRAK
Penelitian pemanfaatan limbah cair hasil produksi Alkali Treated Sargassum telah dilakukan

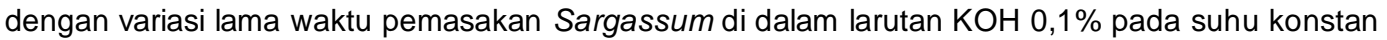
$80{ }^{\circ} \mathrm{C}$. Variasi waktu pemasakan yang diberikan $0,120,240$ dan 360 menit. Tujuan dari penelitian ini untuk mengetahui komposisi kandungan unsur hara makro $(\mathrm{N}, \mathrm{P}, \mathrm{K}), \mathrm{C}_{\text {oranik }}$, rasio $\mathrm{C} / \mathrm{N}$, dan sifat fisik (electrical conductivity, total dissolved solute, nilai kekentalan dan $\mathrm{pH}$ ) limbah cair produksi Alkali Treated Sargassum yang diakibatkan perlakuan suhu pemasakan. Hasil penelitian menunjukkan bahwa limbah cair dari produksi Alkali Treated Sargassum mengandung unsur hara makro $\mathrm{N}$ antara 124-200,5 ppm, P $22-59$ ppm; K 0,078-0,094\%, C ${ }_{\text {orgaik }}$, 2.000-3.550 ppm; rasio C/N antara 15-23, nilai Electrical conductivity (EC) 4,23- 5,90 mS/cm, Total Dissolved Solute (TDS) 0,21- 0,46\%, nilai kekentalan 3,57-4,46 cPs dan pH 8,67-7,12. Perlakuan terbaik berdasarkan nilai tertinggi ditemukan pada perlakuan Sargassum yang dipanaskan pada suhu $80{ }^{\circ} \mathrm{C}$ selama 360 menit dalam larutan $\mathrm{KOH} 0,1 \%$ dengan nilai EC $5,9 \mathrm{mS} / \mathrm{cm}$; TDS $0,46 \%$; pH 7,12; nilai kekentalan 4,64 cPs; kadar N 200,6 ppm; K 0,094 ppm; organik $_{\text {r }} 3.550$ ppm dan C/N 23.
\end{abstract}

KATA KUNCI : Alkali Treated Sargassum, limbah cair, unsur hara makro, pupuk cair

\section{ABSTRACT}

Research on the utilization of liquid waste from Alkali Treated Sargassum processing was carried out by variation of cooking time of Sargassum in $0.1 \% \mathrm{KOH}$ at constant temperature of $80{ }^{\circ} \mathrm{C}$. Cooking time was varied $0,120,240$ and 360 minutes. The objective of this research was to evaluate macro nutrient content $(N, P, K), C_{\text {organic }}, C / N$ ratio, and physical properties (electrical conductivity, total dissolved solute, viscosity value and $\mathrm{pH}$ value) of the liquid waste, due to the cooking time treatment. Result of the experiment showed that liquid waste from Alkali Treated

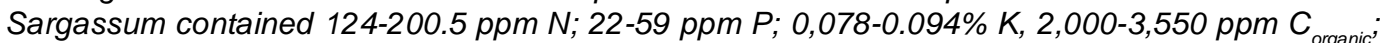
15-23 C/N ratio, 4.23-5.90 mS/cm Electrical conductivity (EC), 0.21-0.46\% Total Dissolved Solute (TDS), 3.57-4.46 cPs viscosity value and $\mathrm{pH}$ 8.67-7.12. The best treatment based on the macro nutrient value and physical properties was cooking the liquid waste in hot $0.1 \% \mathrm{KOH}$ solution at 80 ${ }^{\circ} \mathrm{C}$ time for 360 minutes, in which the properties of the liquid waste was $5.9 \mathrm{mS} / \mathrm{cm} \mathrm{EC}$ value; $0.46 \%$ TDS; pH 7.12; 4.64 cPs viscocity; 200.6 ppm N content; 0.094 ppm K content; 3,550 ppm $C_{\text {organic }}$ and $23 \mathrm{C} / \mathrm{N}$ ratio.

\section{KEYWORDS: Alkali Treated Sargassum, liquid waste, macro nutrient, liquid fertilizer}

\section{PENDAHULUAN}

Teknik pengawetan Sargassum menjadi Alkali Treated Sargassum mengacu pada penelitian Anwar, Djunaedi, dan Santosa (2013); Basmal, Yunizal, dan Tazwir (1998), Darmawan, Tazwir, dan Hak (2006), dan Husni, Subaryono, Pranoto, Tazwir, dan Ustadi (2012), bahwa perlakuan menggunakan larutan $\mathrm{KOH} 0,1 \%$ dapat meningkatkan kualitas sodium alginat tetapi juga menciptakan limbah cair. Selanjutnya dilaporkan untuk memproses Sargassum menjadi Alkali Treated Sargassum dibutuhkan larutan $\mathrm{KOH} 0,1 \%$ dengan rasio 1 bagian Sargassum: $6-10$ bagian larutan $\mathrm{KOH}$ $0,1 \%$ dan larutan tersebut belum dimanfaatkan secara maksimal. Tujuan perlakuan menggunakan larutan $\mathrm{KOH}$ adalah untuk meningkatkan kualitas alginat 
dalam talus Sargassum serta untuk menghilangkan unsur hara mikro, unsur hara makro, zat pengatur tumbuhan, protein, lemak dan vitamin yang ada dalam talus rumput laut Sargassum. Beberapa hasil penelitian menyebutkan di dalam talus Sargassum sp. terkandung unsur hara makro $(N, P, K)$, unsur hara mikro (Ca, Cu, Fe, Mg, Mn, Na, S, Zn, Boron), asam humid, tanin, iodin, zat pengatur tumbuh (auksin, giberelin, sitokinin-kinetin, sitokinin-zeatin), fenol dan vitamin. Sedangkan Handayani, Sutarno, dan Setyawan (2004) melaporkan dalam rumput laut $S$. crassifolium terkandung protein $5,19 \%(\mathrm{~b} / \mathrm{b})$ yang terdiri dari 17 jenis asam amino, mineral $36,93 \%$ (w/ w), Ca 1540,66 mg/100g, Fe 132,65 mg/100g, P $474,03 \mathrm{mg} / 100 \mathrm{~g}$, vitamin C 49,01 mg/100g, vitamin A: $489,11 \mathrm{mg} \mathrm{RE} / 100 \mathrm{~g}$, lemak/lipid 1,63\% (w/w), asam lemak (asam laurat $1,45 \%$, asam miristat $3,53 \%$, asam palmitat $33,59 \%$, asam oleat $13.78 \%$, asam linoleat 33.58\%, dan asam linolenat 5.94\%).

Kompleknya kandungan kimia dan zat aktif yang ada di dalam Sargassum spp. ini menjadi alasan limbah proses Alkali Treated Sargassum telah digunakan sebagai pupuk tanaman. Latique, Chernane, Mansori dan El Kaoua (2013) melaporkan penggunaan cairan rumput laut dapat meningkatkan kualitas klorofil buncis karena rumput laut mengandung semua unsur yang diperlukan oleh tanaman buncis disamping itu cairan rumput laut juga mengandung zat hormon tumbuh. Basmal, Kusumawati, dan Utomo (2015) dan Sedayu, Erawan, dan Assadad (2014) menyatakan bahwa dalam cairan rumput laut terkandung zat tumbuh seperti auksin, sitokininzeatin, sitokinin-kinetin dan gibberellin; Metha et al., (1967) dan Bokil et al., (1974) dalam Latique et al., (2013) melaporkan bahwa cairan rumput laut sangat menguntungkan apabila diaplikasikan dalam bentuk disemprotkan ke bunga "foliar spray" pada tanam cereal "ceral crops", sayuran, buah-buahan dan bunga serta tanaman hortikultura lainnya. Untuk menentukan berapa dosis yang cocok penggunaan cairan rumput laut sebagai pupuk dapat digunakan Electrical Conductivity (EC) meter untuk menentukan tegangan listrik yang ada dalam cairan limbah proses Alkali Treated Sargassum. Menurut Soeseno (1999) konsentrasi garam mineral seperti $\mathrm{Ca}, \mathrm{K}, \mathrm{Mg}, \mathrm{Na}$, $\mathrm{Fe}, \mathrm{Cu}, \mathrm{Zn}, \mathrm{S}, \mathrm{P}$, dan $\mathrm{Mn}$ yang ada dalam suatu larutan dapat diukur menggunakan EC meter, semakin tinggi nilai EC suatu larutan berarti makin pekat kandungan garam mineral dalam larutan tersebut sehingga kemampuan menghantarkan arus listrik makin tinggi. Sedangkan Untung (2000) dalam Sutiyoso (2003) menyebutkan nilai EC sangat penting dalam budidaya tanaman dengan sistem hidroponik. Untuk tanaman yang belum dewasa kisaran EC yang dipersyaratkan antara 1-1,5 mS/cm dan menjelang berbunga antara 2,5-4 mS/cm kecuali tanaman tomat dapat mencapai nilai EC $7 \mathrm{mS} / \mathrm{cm}$.

Kepekatan Iarutan nutrisi dipengaruhi oleh kandungan garam total serta akumulasi ion-ion yang ada dalam larutan nutrisi. Konduktivitas listrik dalam larutan mempengaruhi metabolisme tanaman, yaitu dalam hal kecepatan fotosintesis, aktivitas enzim dan potensi penyerapan ion-ion oleh akar. Kepekatan larutan nutrisi juga akan menentukan lama penggunaan larutan nutrisi dalam sistem hidroponik. Pertumbuhan tanaman tidak hanya dipengaruhi oleh konsentrasi unsur hara makro dan mikro tetapi juga ditentukan dari tingkat keasaman tanah. Seswati, Nurmiati, dan Priadnad (2013) melaporkan nilai pH 8 merupakan nilai pH optimum untuk pertumbuhan jamur Tiram coklat. Tujuan penelitian ini adalah untuk mendapatkan perlakuan optimum dalam rangka pemanfaatan limbah cair dari proses produksi Alkali Treated Sargassum sebagai bahan baku pupuk cair.

\section{BAHAN DAN METODE}

\section{Bahan}

Bahan baku yang digunakan adalah Sargassum sp dengan tingkat kekeringan $16,08 \%(b / b)$, kadar abu $30,45 \%$, dan kadar protein $7,30 \%$ asal pantai Binuangeun-Banten. Setelah rumput laut dipanen, dicuci dengan air laut kemudian dikeringkan di bawah sinar matahari. Sargassum yang sudah kering kemudian dibawa ke Laboratorium Balai Besar Riset Pengolahan Produk dan Bioteknologi Jakarta untuk diolah menjadi Alkali Treated Sargassum dengan jenis larutan bahan kimia yang digunakan adalah larutan $\mathrm{KOH}$ teknis $0,1 \%$. Larutan $\mathrm{KOH}$ yang tersisa setelah pengolahan Sargassum menjadi Alkali Treated Sargassum dikumpulkan untuk dianalisis.

\section{Metode}

Metode penelitian ini mengacu pada Basmal et al. (1998) yakni Sargassum yang diperoleh dari pantai Binuangeun dicuci dengan air tawar untuk menghilangkan kotoran dan garam yang menempel pada talus Sargassum. Larutan KOH 0,1\% dengan volume 6 kali berat rumput laut disiapkan, kemudian dipanaskan hingga suhu mencapai $80^{\circ} \mathrm{C}$. Sargassum yang sudah dibersihkan tersebut kemudian dimasukkan ke dalam larutan $\mathrm{KOH} 0,1 \%$ panas dengan perlakuan yang diberikan adalah lama pemanasan berturut turut: 120 menit, 240 menit dan 360 menit, kecuali SK (kontrol) direndam dalam larutan $\mathrm{KOH} 0,1 \%$ pada suhu kamar selama 360 menit (Gambar 1). Untuk mendapatkan data yang lebih akurat percobaan ini dilakukan sebanyak 3 kali 
ulangan. Sargassum yang telah mendapatkan perlakuan tersebut kemudian dipisahkan dari cairan $\mathrm{KOH}$ yang tersisa untuk dilakukan pengamatan terhadap kandungan unsur hara makro kadar nitrogen (N) dengan SNI. 01-2354.4-2006BSN (2006). Analisis unsur hara $\mathrm{P}$, dan $\mathrm{K}, \mathrm{C}_{\text {organik }}$ menggunakan atomic absorption spectrophotometer (AAS)-AES Agilent MP (AAS-MPAES), nilai pH diukur menggunakan $\mathrm{pH}$ meter merk orion 4 star, nilai kekentalan diukur menggunakan Brookfield meter model LVT nomor seri 8545043, TDS dan EC diukur menggunakan electrometer merk HM COM-80 untuk hidroponik dan kualitas air. Sedangkan nilai rendemen diukur dengan cara memisahkan cairan dari Sargassum yang sudah dimasak. Volume cairan yang diperoleh diukur dengan gelas ukur.

\section{HASIL DAN BAHASAN}

\section{Rendemen}

Cairan media pelarut unsur hara mikro dan makro yang tertinggal setelah proses perlakuan berkisar antara $52,38 \pm 0,10 \%-62,12 \pm 1,95 \%$ (b/b) dengan nilai terendah ditemukan pada perlakuan pemasakan 360 menit sebesar $52,38 \pm 0,10 \%$ kemudian diikuti oleh perlakuan kontrol $(52,95 \pm 0,14 \%)$, perlakuan pemasakan 120 menit $(60,62 \pm 0,54 \%)$ dan perlakuan pemasakan 240 menit $(62,12 \pm 1,95 \%)$ (Gambar 2). Rasio antara Sargassum dengan media pelarut unsur hara mikro dan makro adalah berbanding 1:6. Rumput laut kering pada saat direndam akan menyerap sejumlah air masuk ke dalam talus Sargassum sehingga jumlah media pelarut akan berkurang. Pada perlakuan waktu pemasakan 0 menit jumlah media pelarut yang masuk ke dalam talus Sargassum selama proses perendaman pada suhu kamar sebesar $47,05 \%$ sehingga pada saat pemisahan talus Sargassum dari media pelarut masih tersisa sebesar $52,95 \%$. Media pelarut yang masuk ke dalam talus berupa air bebas yang dapat keluar ketika ada perlakuan. Pada perlakuan waktu pemasakan 120 menit yakni Sargassum yang telah dimasak pada suhu $80^{\circ} \mathrm{C}$ selama 120 menit menggunakan $\mathrm{KOH}$ teknis $0,1 \%$ jumlah cairan yang tersisa sebesar $60,62 \%$.

Dibandingkan perlakuan kontrol, adanya peningkatan volume cairan yang tersisa pada perlakuan waktu pemasakan 120 menit dan 240 menit, (kecuali perlakuan waktu pemasakan 360 menit), karena talus yang sudah dimasak diberi perlakuan pengepresan untuk mengeluarkan cair dari dalam talus Sargassum. Pada perlakuan waktu pemasakan 120 menit dibandingkan dengan perlakuan waktu pemasakan 0 menit ada selisih penambahan cairan yang dapat ditarik kembali sebesar $7,67 \%$, sedangkan dengan perlakuan waktu pemasakan 240 menit jumlah pelarut yang dapat ditarik kembali lebih besar dibandingkan dengan perlakuan waktu pemasakan 0 menit yakni sebesar $9,17 \%$. Antara perlakuan waktu pemasakan 120 menit dan 240 menit nilai tertinggi rendemen ditemukan pada perlakuan waktu pemasakan 240 menit dengan selisih sebesar $1,50 \%$. Pada perlakuan waktu pemasakan 360 menit terjadi penurunan jumlah cairan ekstrak, hal ini mungkin selama proses

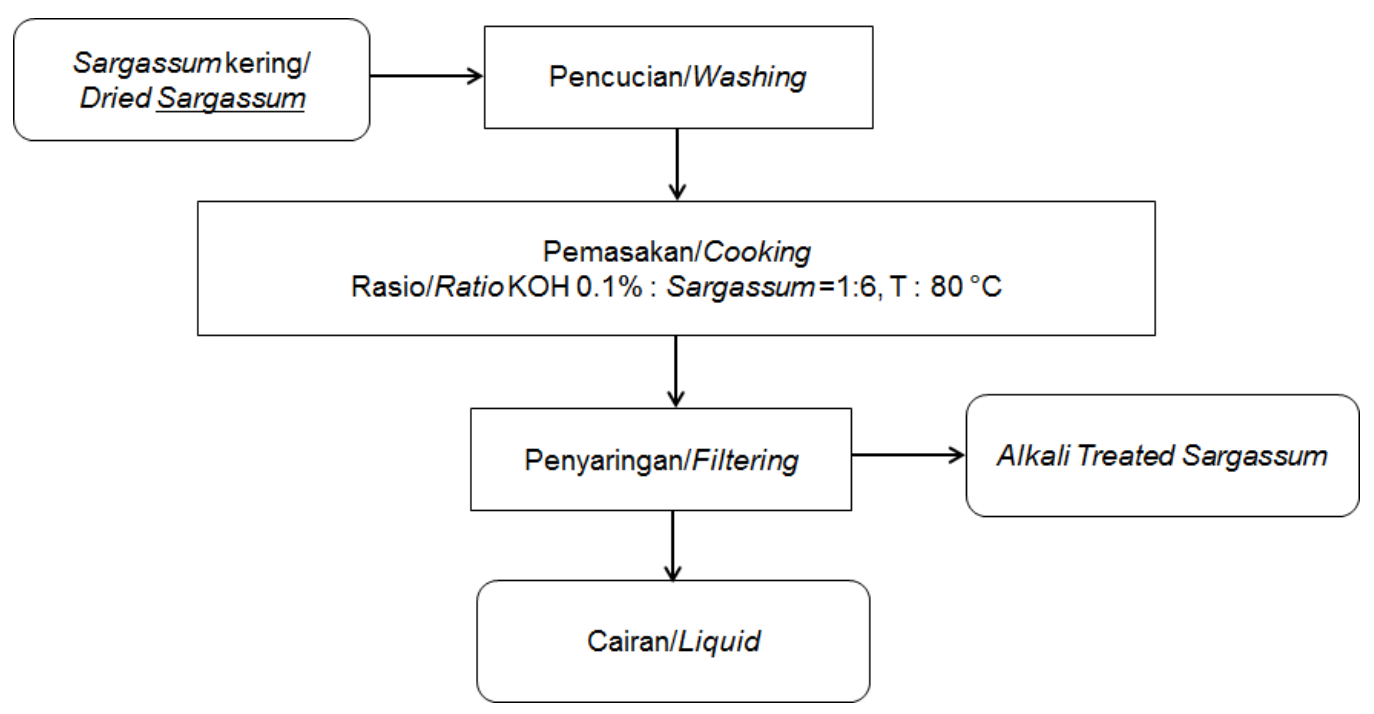

Gambar 1. Diagram alir pengambilan cairan dari proses produksi Alkali Treated Sargassum Figure 1. Flowchart of liquid extraction from Alkali Treated Sargassum process 
pemanasan telah terjadi proses penguapan air. Jumlah uap air atau air yang hilang selama proses pemanasan adalah paralel dengan waktu pemanasan yang diberikan.

Di samping itu, proses penarikan sejumlah air dari suatu bahan juga akan sangat tergantung pada kondisi fisik bahan yang dipanaskan. Jika uap air terikat kuat dalam sel bahan maka kecepatan penguapan pada suhu tertentu akan berjalan lambat. Telah diketahui bahwa kadar air dalam bahan pangan dapat dibagi menjadi 3 fase yakni air yang berada dalam sel, air terikat antara sel dan air bebas. Air yang berada dalam sel memerlukan energi panas yang tinggi untuk dapat dikeluarkan dan diuapkan dari sel, sedangkan air bebas akan sangat mudah diuapkan tetapi juga tergantung pada kondisi fisik bahan yang dipanaskan. Proses induksi panas ke dalam bahan pangan dalam waktu tertentu akan menyebabkan dinding sel menjadi lunak dan sebagai akibatnya sejumlah uap air akan lebih mudah keluar dari bahan pangan. Dalam penelitian ini, perlakuan waktu pemasakan 360 menit mendapatkan sejumlah energi panas lebih lama dari perlakuan waktu pemasakan 240 menit, 120 menit dan 0 menit sehingga media pelarut unsur hara mikro dan makro dari dalam Sargassum lebih banyak teruapkan dibandingkan dengan perlakuan lainnya.

Nilai rendemen akan sangat dipengaruhi oleh proses pereaksi antara larutan $\mathrm{KOH}$ dengan unsur hara yang ada dalam rumput laut. Lamanya waktu kontak antara Sargassum dengan media pelarut unsur hara akan berpengaruh pada volume rendemen yang dihasilkan. Jumlah unsur hara yang dapat bereaksi dengan pelarut dipengaruhi pula oleh lamanya waktu kontak, konsentrasi pelarut, luas permukaan, temperatur dan katalis yang digunakan. Berdasarkan teori tumbukan, laju reaksi akan meningkat 2 kali jika suhu dinaikkan $10^{\circ} \mathrm{C}$. Suhu yang tinggi selama proses reaksi akan menghasilkan energi gerak atau energi kinetik molekul yang tinggi pula sehingga tumbukan antara talus rumput laut dengan pelarut unsur hara semakin sering dan sebagai akibatnya sejumlah unsur hara dalam talus rumput laut akan tertarik keluar. Dalam penelitian ini suhu yang diberikan pada semua perlakuan adalah sama yakni $80^{\circ} \mathrm{C}$ sedangkan waktu pemasakan telah dibedakan. Peranan suhu dalam perlakuan ini di samping untuk meningkatkan reaksi kimia dan memberikan energi potensial juga untuk melunakkan talus rumput laut sehingga proses tumbukan larutan bahan kimia dengan unsur hara yang ada dalam talus lebih mudah.

Pada perlakuan waktu pemasakan 120 menit dan 240 menit, volume cairan lebih tinggi dibandingkan dengan perlakuan kontrol dan waktu pemasakan 360 menit, hal ini dapat disebabkan adanya penambahan cairan yang berasal dari dalam talus Sargassum. Sedangkan pada perlakuan waktu pemasakan 360 menit meskipun ada tambahan cairan yang keluar dari dalam talus Sargassum juga telah diimbangi dengan penguapan air selama pemanasan. Penguapan air yang lebih banyak pada perlakuan waktu pemasakan 360 menit dibandingkan dengan perlakuan lain telah mengakibatkan cairan lebih terkonsentrat sehingga nilai Electrical Conductivity (EC) dan Total Dissolved Solids (TDS) lebih tinggi dari perlakuan lainnya. Hasil penelitian yang dilakukan Zailanie, Susanto, dan Simon (2001) menyatakan bahwa lama waktu

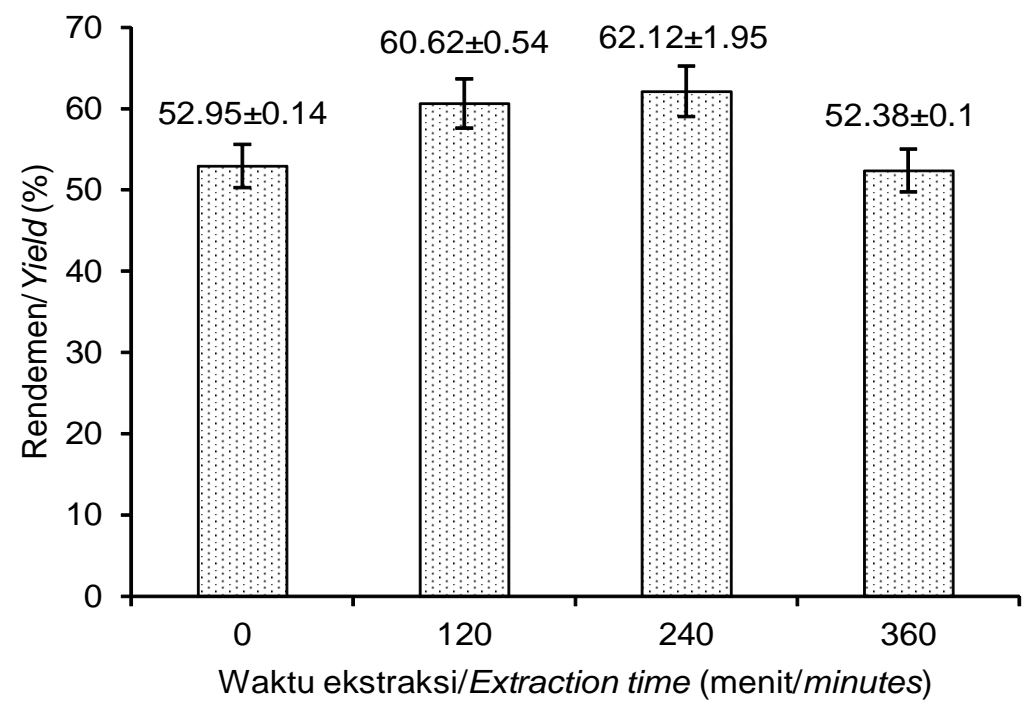

Gambar 2. Nilai rendemen dari cairan proses pengolahan Alkali Treated Sargassum Figure 2. Yield of liquid of Alkali Treated Sargassum 
ekstraksi telah berpengaruh terhadap rendemen alginat yang dihasilkan.

\section{Nilai Electrical Conductivity (EC)}

Hasil penelitian menunjukkan bahwa nilai EC berkisar antara 4,23 $\pm 0.07 \mathrm{mS} / \mathrm{cm}-5,90 \pm 0,71 \mathrm{mS} / \mathrm{cm}$ dengan nilai tertinggi ditemukan pada perlakuan waktu pemasakan 360 menit sebesar $5,90 \pm 0,71 \mathrm{mS} /$ $\mathrm{cm}$ kemudian berturut turut diikuti oleh perlakuan waktu pemasakan 240 menit $(4,85 \pm 0.01 \mathrm{mS} / \mathrm{cm}), 120$ menit $(4,65 \pm 0,40 \mathrm{mS} / \mathrm{cm}), 0$ menit $(4,23 \pm 0,07 \mathrm{mS} /$ $\mathrm{cm})$. Pada Gambar 3 dapat dilihat nilai EC masingmasing perlakuan.

Hasil uji statistik persamaan garis antar perlakuan telah membentuk suatu persamaan garis polynomial $y=0,1798 x^{3}-1,1905 x^{2}+2,7327 x+2,508$ dengan nilai $r^{2}=1$ yang berarti lamanya waktu induksi panas pada suhu konstan $80^{\circ} \mathrm{C}$ ke dalam talus Sargassum berpengaruh terhadap sejumlah ion positif dan negatif dalam larutan $\mathrm{KOH}$ 0,1\%. Semakin lama Sargassum kontak dengan suhu $80^{\circ} \mathrm{C}$ semakin banyak ion positif dan negatif yang dapat dikeluarkan dari dalam talus Sargassum. Peningkatan ion positif dan negatif dalam larutan $\mathrm{KOH} 0,1 \%$ mengakibat peningkatan nilai EC. Jumlah ion positif dan negatif yang ke luar dari dalam talus Sargassum telah diukur menggunakan EC meter dan pada perlakuan ini nilai EC tertinggi ditemukan pada perlakuan waktu pemasakan 360 menit sebesar $5,9 \mathrm{mS} / \mathrm{cm}$. Waktu pemanasan pada suhu konstan $80^{\circ} \mathrm{C}$ berhubungan erat dengan jumlah ion positif dan negatif yang ke luar dari dalam talus Sargassum, pemberian energi panas telah menyebabkan dinding sel talus menjadi lunak dan tingkat kelunakan tergantung berapa lama Sargassum kontak dengan energi panas. Pada perlakuan waktu pemasakan 360 menit waktu kontak lebih lama dari perlakuan waktu pemasakan 240 menit, 120 menit dan kontrol sehingga jumlah ion positif dan negatif yang keluar juga berpengaruh. Mengacu pada pernyataan Sutiyoso (2004) syarat minimum pupuk hidroponik harus memiliki nilai EC 2,5 mS/cm. Dalam penelitian ini nilai EC semua perlakuan di atas $2,5 \mathrm{mS} / \mathrm{cm}$ artinya media pengolahan Alkali Treated Sargassum dapat digunakan sebagai bahan alternatif pembuatan pupuk untuk tanaman hidroponik.

\section{Nilai Kekeruhan/Total Dissolved Solid (TDS)}

Nilai TDS berbanding lurus dengan nilai EC dan dari hasil pengukuran nilai TDS berkisar antara 2,10 $\pm 0,05 \%-2,98 \pm 0,04 \%$ (Gambar 4) dengan nilai tertinggi ditemukan pada perlakuan waktu pemasakan 360 menit $(2,98 \pm 0,04 \%)$, sedangkan nilai terendah pada perlakuan waktu pemasakan 0 menit $(2,10 \pm 0,05 \%)$. Nilai TDS sangat dipengaruhi oleh banyaknya ion positif, negatif dan partikel terlarut dalam media pelarut cairan Sargassum. Total zat padat terlarut (TDS) adalah semua zat-zat padat berupa bahan organik maupun anorganik, berupa molekul yang terionkan atau dalam bentuk mikro granula (sol koloida) yang terperangkap di dalam suatu cairan. Banyaknya TDS yang terlarut di dalam suatu cairan akan sangat tergantung pada banyaknya bahan padatan yang terurai akibat adanya perlakuan waktu, suhu dan konsentrasi dan sifat bahan kimia yang digunakan sebagai pelarut unsur hara mikro dan

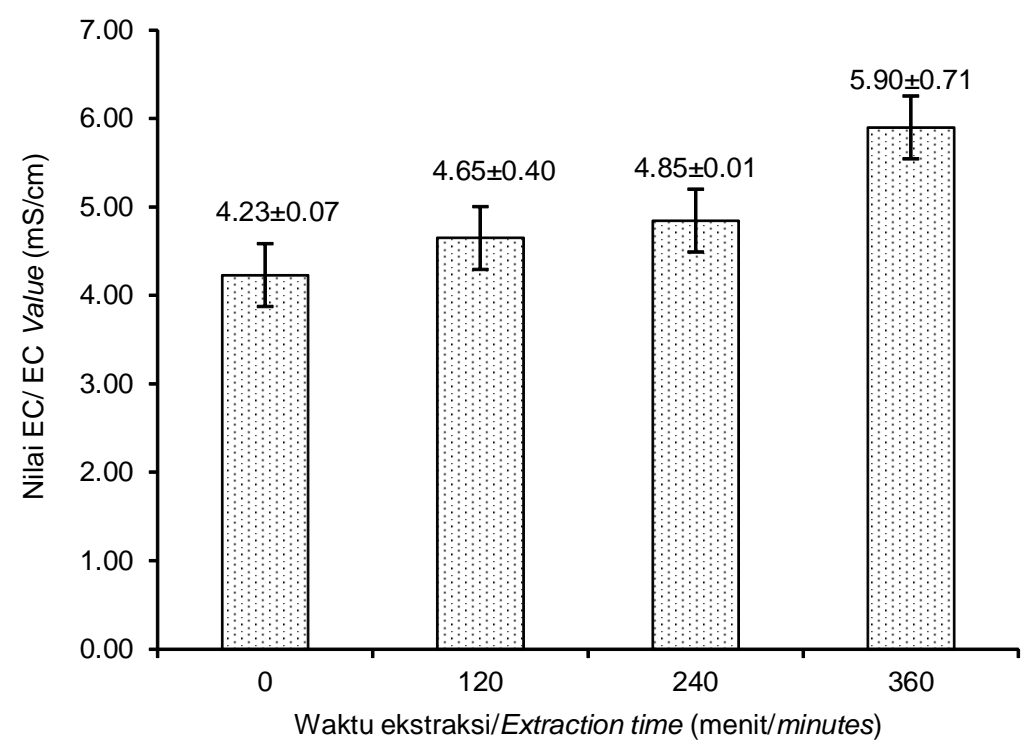

Gambar 3. Nilai electrical conductivity dari cairan proses pengolahan Alkali Treated Sargassum Figure 3. Electrical conductivity value of liquid of Alkali Treated Sargassum 
makro. Dalam penelitian ini jenis larutan yang digunakan adalah larutan $\mathrm{KOH} 0,1 \%$ dengan rasio

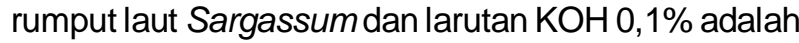
1 bagian Sargassum : 6 bagian larutan $\mathrm{KOH} \mathrm{0,1 \% .}$

Hasil uji statistik persamaan garis menunjukkan bahwa kurva hubungan antara perlakuan berbentuk persamaan garis polynomial $y=0,0102 x^{3}-0,0668 x^{2}+$ $0,1495 x+0,1173$ dengan nilai $r^{2}=1$ artinya jumlah TDS yang dapat dikeluarkan dari dalam talus Sargassum pada setiap perlakuan waktu pada suhu pemasakan yang konstan $80^{\circ} \mathrm{C}$ menunjukkan hubungan yang erat, semakin lama waktu kontak Sargassum dengan pelarut maka semakin banyak TDS yang dihasilkan. Hal ini dimungkinkan karena waktu kontak yang lama telah menyebabkan talus Sargassum menjadi lebih lunak sehingga banyak TDS yang keluar dari dalam talus Sargassum. Pada perlakuan waktu pemasakan 360 menit waktu kontak Sargassum dengan pelarut lebih lama dibandingkan dengan perlakuan 240 menit, 120 menit dan 0 menit.

Fungsi perlakuan suhu pada proses penelitian ini adalah untuk memperlunak tekstur talus Sargassum sehingga mempercepat proses pelarutan unsur hara dari talus Sargassum. Secara teori dikatakan suhu berperan dalam mempercepat rekasi kimia dan proses ini akan lebih cepat bila dikombinasikan dengan konsentrasi pelarut dan lama waktu kontak bahan dengan pelarut. Kandungan TDS yang terdapat dalam setiap perlakuan dapat berupa unsur hara makro seperti N-P-K dan C (organik) dan unsur hara mikro: $\mathrm{Fe}, \mathrm{Zn}, \mathrm{Mn}, \mathrm{Mg}, \mathrm{Cu}$, dan Boron. Menurut Basmal (2010) dan Sedayu, Basmal dan Utomo (2013) dalam cairan rumput laut masih terdapat unsur hara makro dan mikro serta hormon pertumbuhan seperti auksin, giberelin dan sitokinin.

Dari hasil uji statistik persamaan garis hubungan antara TDS dan EC ditemukan persamaan garis dalam bentuk polynomial: $y=0,1798 x^{3}-1,1905 x^{2}+2,7327 x$ +2.508 dengan nilai $r^{2}=1$. Ini berarti bahwa peningkatan nilai TDS akan diikuti pula oleh peningkatan nilai EC. Semakin tinggi nilai TDS akan semakin tinggi pula unsur hara dari dalam talus Sargassum yang terlarut dalam media pelarut $\mathrm{KOH}$ $0,1 \%$.

\section{Nilai pH}

Hasil pengukuran nilai $\mathrm{pH}$ cairan proses pengolahan Alkali Treated Sargassum setelah digunakan untuk menarik cairan dari dalam talus Sargassum berkisar antara 6,67 $\pm 0,28-7,12 \pm 0,08$. Nilai $\mathrm{pH}$ tertinggi dihasilkan pada perlakuan lama proses pemasakan 360 menit, yaitu 7,12 $\pm 0,08$ kemudian diikuti berturut turut oleh perlakuan waktu pemasakan 240 menit $(6,92 \pm 0,13)$, perlakuan waktu pemasakan 120 menit $(6,87 \pm 0,03)$ dan perlakuan waktu pemasakan 0 (nol) menit $(6,67 \pm 0,28)$. Adanya perbedaan nilai $\mathrm{pH}$ ini tidak lain disebabkan oleh pemberian perlakuan waktu yang berbeda. Larutan $\mathrm{KOH} 0,1 \%$ adalah bersifat basa sedangkan rumput laut Sargassum bersifat asam. Pencampuran antara larutan $\mathrm{KOH}$ yang bersifat basa dengan rumput laut yang sedikit bersifat asam akan menghasilkan nilai $\mathrm{pH}$ baru.

Nilai $\mathrm{pH}$ yang terbentuk sangat tergantung berapa lama rumput laut kontak dengan media yang bersifat

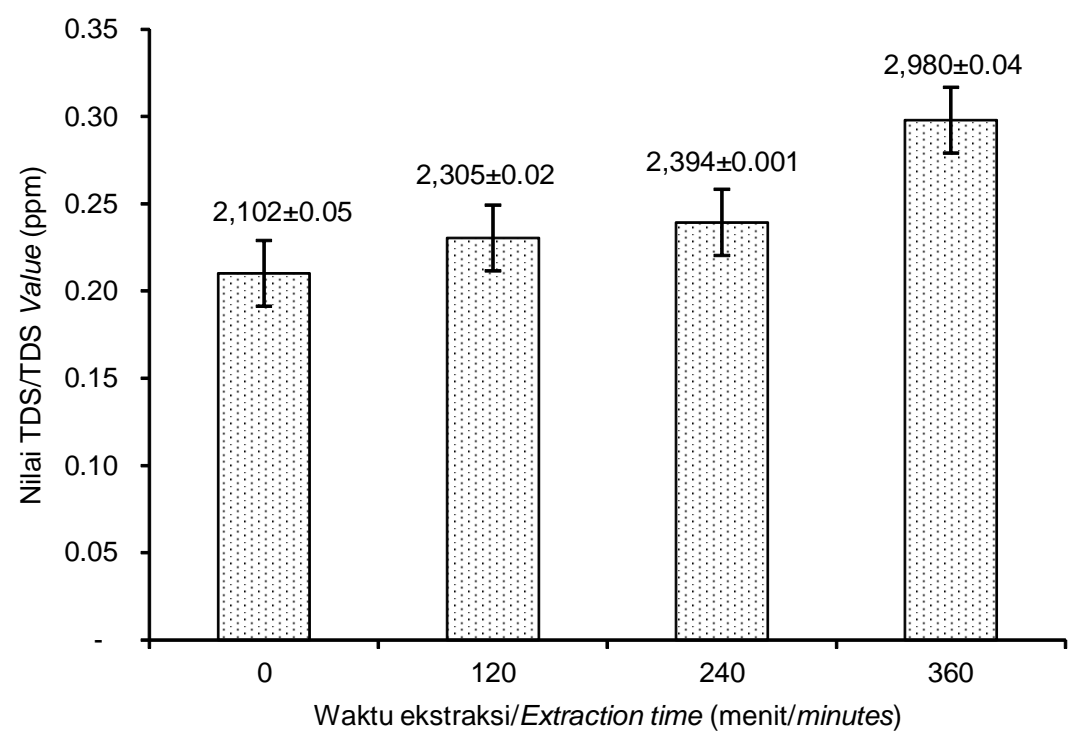

Gambar 4. Nilai TDS dari cairan proses pengolahan Alkali Treated Sargassum Figure 4. TDS value of liquid of Alkali Treated Sargassum 
basa. Kecepatan perubahan nilai pH juga tidak hanya dipengaruhi oleh lama kontak bahan dengan media pelarut tetapi juga dipengaruhi oleh sifat fisik bahan. Semakin keras bahan yang direndam dalam larutan yang bersifat basa maka reaksi perubahan nilai $\mathrm{pH}$ akan lambat. Tingkat kekerasan tekstur bahan dapat diperlunak dengan memberikan energi panas. Energi panas yang diberikan akan membuka pori pori talus sehingga penitrasi larutan ke dalam dinding sel talus akan lebih mudah. Pada perlakuan waktu pemasakan 360 menit menyebabkan waktu kontak dengan pelarut lebih lama dibandingkan dengan perlakuan waktu pemasakan 0 menit, 120 menit dan 240 menit sebagai akibatnya tekstur talus lebih lunak sehingga reaksi antara cairan dalam talus Sargassum dengan media pelarut akan lebih mudah terjadi sebagai akibatnya nilai pH akan berubah lebih besar dari perlakuan lainnya (Gambar 5).

Pada Gambar 5 terlihat bawa perlakuan waktu pemasakan 0 menit, 120 menit dan 240 menit lebih bersifat asam dibandingkan dengan perlakuan waktu pemasakan 360 menit. Nilai $\mathrm{pH}<7$ dikatagorikan bersifat asam artinya kandungan ion $\mathrm{H}^{+}$lebih banyak di dalam cairan pengolahan Sargassum menjadi Alkali Treated Sargassum, sedangkan nilai $\mathrm{pH}>7$ dikatagorikan cairan lebih bersifat basa artinya ion $\mathrm{OH}^{-}$lebih banyak dari pada ion $\mathrm{H}^{+}$. Pada umumnya, semakin meningkat kandungan asam suatu bahan maka nilai $\mathrm{pH}$ akan semakin turun. Menurut Sutiyoso (2003) pada budidaya hidroponik dipilih kisaran $\mathrm{pH}$ 5,5-6,5 dengan demikian $\mathrm{pH}$ pupuk cair organik diharapkan berada pada kisaran $\mathrm{pH}$ tersebut.Sedangkan berdasarkan persyaratan teknis minimal pupuk cair organik yang di tetapkan oleh
Permentan (2011) mengenai standar mutu pupuk cair organik yaitu memiliki nilai $\mathrm{pH}$ sebesar 4 sampai dengan 9. Diduga selama proses pemasakan Sargassum dalam larutan $\mathrm{KOH} \mathrm{0,1 \%} \mathrm{sebagian} \mathrm{mineral}$ seperti $\mathrm{Mg}, \mathrm{Mn}, \mathrm{Fe}, \mathrm{Cu}$ dan Boron akan terlepas dari dalam talus dan bereaksi dengan ion $\mathrm{OH}$ membentuk garam mineral yang bersifat basa, sedangkan ion $\mathrm{K}$ dari larutan $\mathrm{KOH} 0,1 \%$ akan bereaksi dengaan alginat membentuk kalium alginat. Semakin banyak garam mineral terlepas dari talus Sargassum maka cairan akan menjadi bersifat basa. Hasil perhitungan dengan membandingkan nilai $\mathrm{pH}$ pada perlakuan waktu pemasakan 0 menit dengan 360 menit (Gambar 5) terdapat selisih peningkatan nilai $\mathrm{pH} 0,45$ dengan nilai tertinggi pada perlakuan waktu pemasakan 360 menit.

\section{Nilai Kekentalan}

Hasil pengukuran nilai kekentalan cairan proses Alkali Treated Sargassum berkisar antara 3,57 $\pm 0,18$ $4,64 \pm 0,24 \mathrm{cPs}$ (Gambar 6). Nilai kekentalan tertinggi ditemukan pada perlakuan waktu pemasakan selama 360 menit sebesar 4,64 $\pm 0,24 \mathrm{cPs}$, kemudian diikuti oleh perlakuan pemasakan selama 240 menit sebesar $4,13 \pm 0,05 \mathrm{cPs}$, perlakuan pemasakan selama 120 menit sebesar $3,91 \pm 0,11$ cPs dan terkecil pada perlakuan pemasakan 0 (nol) menit sebesar $3,58 \pm 0,18$ cPs. Dibandingkan dengan perlakuan waktu pemasakan 0 menit terdapat peningkatan nilai kekentalan pada perlakuan waktu pemasakan 120 menit sebesar (9,52\%), 240 menit (15,69\%) dan 360 menit (29,97\%). Adanya perbedaan tingkat kekentalan disebabkan pemberian waktu perlakuan yang berbeda yakni pada perlakuan waktu pemasakan 120 menit, 240 menit dan 360 menit pada suhu $80^{\circ} \mathrm{C}$ dalam larutan

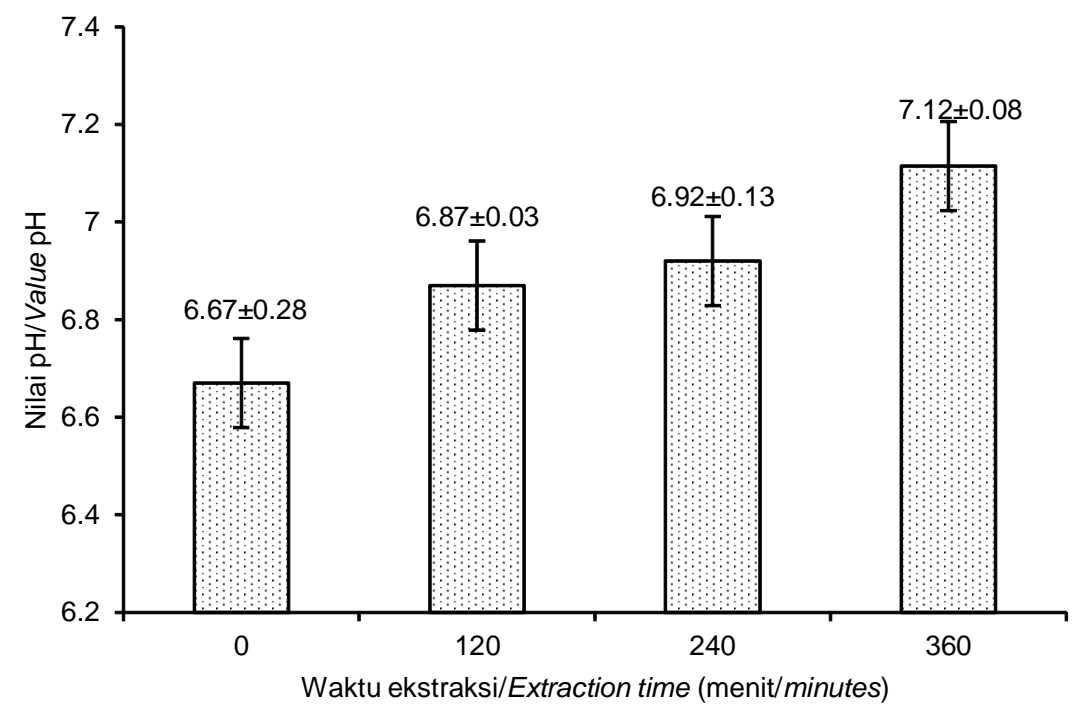

Gambar 5. Nilai pH dari cairan proses pengolahan Alkali Treated Sargassum Figure 5. $\mathrm{pH}$ value of liquid of Alkali Treated Sargassum 
$\mathrm{KOH}$ 0,1\%. Zailanie et al (2001) melaporkan bahwa konsentrasi $\mathrm{KOH}$ dan lama proses pengolahan telah berpengaruh terhadap nilai viskositas. Diduga sejumlah kation seperti kation divalent $\mathrm{Ba}, \mathrm{Pb}, \mathrm{Cu}, \mathrm{Cd}, \mathrm{Zn}, \mathrm{Ni}$, $\mathrm{Co}, \mathrm{Mn}, \mathrm{Fe}$ dan $\mathrm{Mg}$ yang ke luar dari dalam talus Sargassum selama proses pengolahan turut telah mempengaruhi nilai kekentalan (Basmal et al, 2013). Adanya perlakuan waktu pemasakan yang berbeda telah menyebabkan sejumlah cairan alginat ke luar dari dalam talus Sargassum yang kemudian cairan alginat tersebut bereaksi dengan kation monovalent $\mathrm{K}^{+}$dan kation divalent $\mathrm{Pb}, \mathrm{Cu}, \mathrm{Cd}, \mathrm{Zn}, \mathrm{Ni}, \mathrm{Co}, \mathrm{Mn}, \mathrm{Fe}$ dan Mg membentuk larutan garam alginat yang kental. Tingkat kekentalan akan sangat tergantung pada banyaknya alginat yang ke luar dari dalam talus Sargassum kemudian bereaksi dengan kation mono dan divalent. Ganggang coklat termasuk bahan organik yang mengandung kation mono dan divalent cukup tinggi seperti $\mathrm{Na}, \mathrm{Ca}, \mathrm{K}, \mathrm{Cl}, \mathrm{Mg}, \mathrm{Fe}$ dan $\mathrm{S}$ (Zailanie et al., 2001).

Hasil uji statistik persamaan garis hubungan antara peningkatan atau penurunan nilai kekentalan dengan peningkatan dan penurunan nilai pH menghasilkan persamaan garis polynomial $Y=0,2141 x^{3}-1,605 x^{2}+$ $3,5108 x+4,8$ dengan nilai $r^{2}=1$ sehingga dapat ditarik suatu kesimpulan bahwa nilai kekentalan erat hubungannya dengan nilai pH. Basmal et al. (1998) dan Darmawan et al., (2006) melaporkan perendaman rumput laut Sargassum dalam larutan $\mathrm{KOH} \mathrm{0,1 \%}$ dapat menghasilkan viskositas natrium alginat yang tinggi.

\section{Kadar Nitrogen}

Hasil penelitian menunjukkan nilai $\mathrm{N}$ setiap perlakuan berkisar antara 124,0 $\pm 1,7 \mathrm{ppm}-200,5 \pm 1,2$ ppm (Gambar 7) dengan nilai tertinggi ditemukan pada perlakuan waktu pemasakan 360 menit sebesar 200,5 $\pm 1,2$ ppm sedangkan yang terendah ditemukan pada perlakuan waktu pemasakan 0 menit sebesar $124,0 \pm 1,7$ ppm. Basmal (2010) telah melaporkan bahwa kandungan $\mathrm{N}$ hasil pemasakan Sargassum menggunakan laruan $\mathrm{KOH}$ mempunyai nilai $\mathrm{N}$ sebesar 120 ppm. Hasil analisis kadar N pada rumput laut Sargassum kering sebesar 1,17\% atau setara dengan 11,68 ppm. Menurut Burtin (2003), bahwa rumput laut coklat mengandung protein sebesar 3-9\% dari berat basa. Pada penelitian ini kemampuan maksimum larutan $\mathrm{KOH} 0,1 \%$ pada suhu $80^{\circ} \mathrm{C}$ dengan variasi waktu 0-360 menit hanya mampu menarik $\mathrm{N}$ dari dalam talus Sargassum berkisar antara 124,0 $\pm 1,7-$ $200,5 \pm 1,2$ ppm. Hasil penelitian menunjukkan lama waktu pemasakan dalam larutan $\mathrm{KOH} 0,1 \%$ berpengaruh terhadap penarikan $\mathrm{N}$ dari dalam talus Sargassum dan setelah diuji menggunakan regresi ditemukan persamaan garis polynomial $=11.375 \mathrm{x}^{2}$ $33.325 x+148.88, R^{2}=0,9506$ yang berarti bahwa jumlah unsur hara $\mathrm{N}$ yang dapat bereaksi dengan larutan $\mathrm{KOH} 0,1 \%$ telah dipengaruhi oleh faktor lamanya proses pemasakan. Protein merupakan senyawa organik yang mempunyai molekul - molekul yang kompleks, yang terdiri dari unsur - unsur N, C, $\mathrm{H}, \mathrm{O}$, S dan kadang-kadang juga mengandung unsur hara $\mathrm{P}$ (Kirk \& Othmer, 1951). Pada umumnya protein dapat larut dalam air, larutan asam, alkali dan garamgaram netral. Selanjutnya dikatakan beberapa faktor yang mempengaruhi kelarutan protein adalah konsentrasi ion garam dalam pelarut, suhu dan waktu yang diberikan. Sejumlah ion $\mathrm{K}^{+}$dari larutan $\mathrm{KOH}$ yang terdisosiasi menjadi $\mathrm{K}^{+}$dan $\mathrm{OH}^{+}$berinteraksi dengan ion-ion dari molekul protein dalam Sargassum dan sebagai akibatnya terjadi presipitasi sebagian unsur

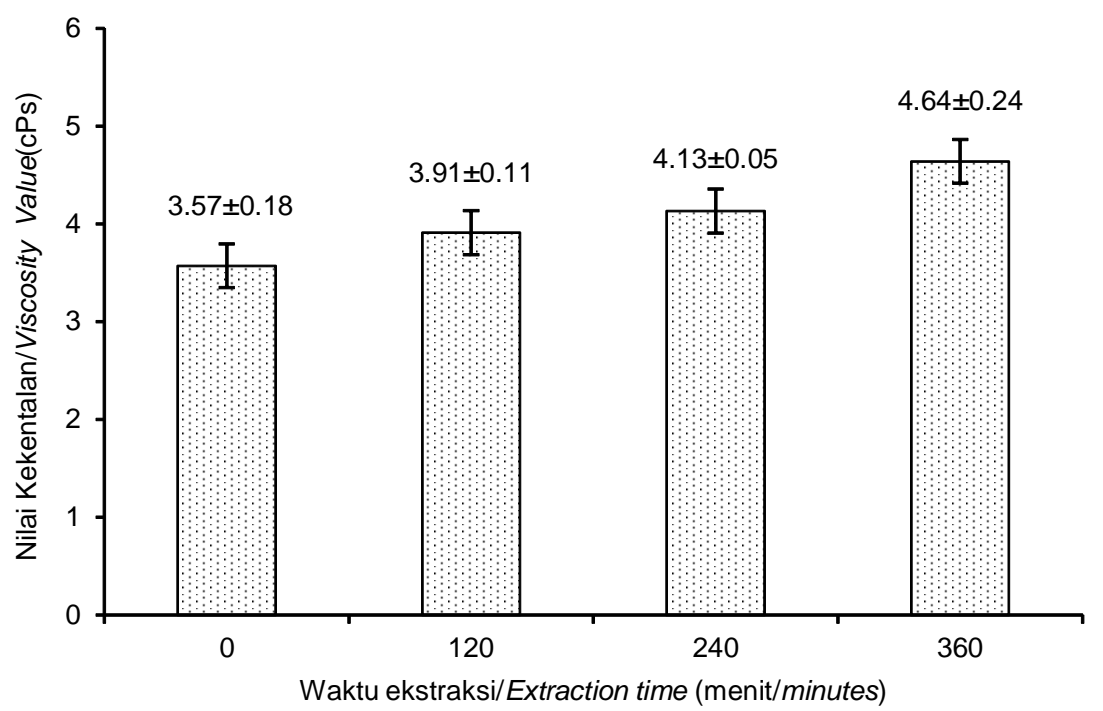

Gambar 6. Nilai kekentalan dari cairan proses pengolahan Alkali Treated Sargassum

Figure 6. Viscocity value of liquid of Alkali Treated Sargassum 
hara N dari dalam talus Sargassum dan proses ini sering disebut sebagai salting in. Bila konsentrasi ion garam pelarut tinggi maka molekul-molekul protein akan diendapkan atau terdenaturasi dan proses ini sering disebut salting out. Ion garam di atau trivalen lebih besar efeknya dari pada garam monovalen. Menurut Yacoba (1951) mekanisme salting out terjadi sangat kompleks, hal ini disebabkan oleh dehidrasi protein oleh garam, di mana ion-ion garam menarik molekul-molekul air dari protein sehingga menurunkan kelarutannya. Berdasarkan teori ini diduga proses pelepasan unsur hara $\mathrm{N}$ dari dalam talus Sargassum ke dalam larutan $\mathrm{KOH} 0,1 \%$ panas tidak maksimal.

Hasil penelitian menunjukkan kandungan protein di dalam rumput laut Sargassum kering pada pH 6,92 adalah sebesar $7,30 \%$ atau setara dengan nilai unsur hara $\mathrm{N}$ sebesar $1,17 \%$ (11,68 ppm). Pada perlakuan kontrol nilai unsur hara sebesar $124,0 \pm 1,7 \mathrm{ppm}$ dan setelah proses perlakuan dalam larutan $\mathrm{KOH} 0,1 \%$ panas $\left(80^{\circ} \mathrm{C}\right)$ selama 120 menit terjadi peningkatan nilai N, semakin lama proses pemasakan Sargassum dalam larutan $\mathrm{KOH} 0,1 \%$ semakin tinggi protein $/ \mathrm{N}$ yang bisa di larutkan dalam pelarut (Gambar 7). Hasil penelitian ini telah sesuai dengan pernyataan Kirk dan Othmer (1951) yang menyatakan jumlah protein/N yang dapat ditarik dari suatu bahan salah satunya tergantung pada lamanya waktu proses yang diberikan.

\section{Kadar Fosfat}

Hasil penelitian menunjukkan kadar $\mathrm{P}_{2} \mathrm{O}_{5}$ berkisar antara 42,0 $\pm 0,8-53,0 \pm 0,1 \mathrm{ppm}$ (Gambar 8) dengan nilai tertinggi pada perlakuan waktu pemasakan 120 menit sebesar 53,0 $\pm 0,1 \mathrm{ppm}$, kemudian berturut turut diikuti oleh perlakuan waktu pemasakan 360 menit sebesar
49,5 $\pm 0,6$ ppm, 240 menit sebesar 49,5 $\pm 0,5$ ppm dan terendah pada perlakuan waktu pemasakan 0 menit sebesar $42 \pm 0,8 \mathrm{ppm}$. Sedangkan kadar $\mathrm{P}_{2} \mathrm{O}_{5}$ pada Sargassumkering sebesar $0,05 \%$ atau setara dengan 500 ppm (Basmal, Kusumawati, Nurhayati \& Hak, 2016).

Rendahnya kadar fosfat yang dapat dikeluarkan dari dalam talus Sargassum dibandingkan dengan total kadar fosfat di dalam talus Sargassum disebabkan konsentrasi larutan $\mathrm{KOH}$ yang dipergunakan masih rendah. Kemungkinan lain fosfat terikat kuat di dalam talus Sargassum dalam bentuk kalsium fosfat. Pada Gambar 8 dapat dilihat bahwa perbedaan waktu perlakuan konsentrasi larutan $\mathrm{KOH}$ $0,1 \%$ dan suhu pemanasan $\left(80^{\circ} \mathrm{C}\right)$ telah menyebabkan kadar $\mathrm{P}_{2} \mathrm{O}_{5}$ bervariasi setiap perlakuan. Waktu perlakuan sangat berperan dalam mengekstrak $\mathrm{P}_{2} \mathrm{O}_{5}$ dari dalam talus Sargassum. Hasil penelitian menunjukkan bahwa pada perlakuan waktu pemasakan 120 menit ditemukan kadar $\mathrm{P}_{2} \mathrm{O}_{5}$ yang tertinggi yakni sebesar 53,0 $\pm 0,1 \mathrm{ppm}$. Sedangkan perlakuan waktu pemasakan 0 menit mempunyai nilai kadar $\mathrm{P}_{2} \mathrm{O}_{5}$ lebih kecil dari perlakuan waktu pemasakan lainnya. Hal ini kemungkinan sejumlah $\mathrm{P}_{2} \mathrm{O}_{5}$ masih terikat kuat di dalam talus Sargassum.

\section{Kadar Kalium}

Hasil penelitian menunjukkan kadar $\mathrm{K}$ yang diperoleh berkisar antara 0,078 $\pm 0,01-0,094 \pm 0,03 \%$ (Gambar 9) dengan nilai tertinggi ditemukan pada perlakuan waktu pemasakan 360 menit sebesar $0,094 \pm 0,003 \%$ kemudian diikuti oleh perlakuan waktu pemasakan 240 menit $(0,085 \pm 0,004 \%), 120$ menit $(0,08 \pm 0,03 \%)$ dan 0 menit $(0,078 \pm 0,01 \%)$. Peningkatan kadar K paralel dengan lamanya waktu pemasakan.

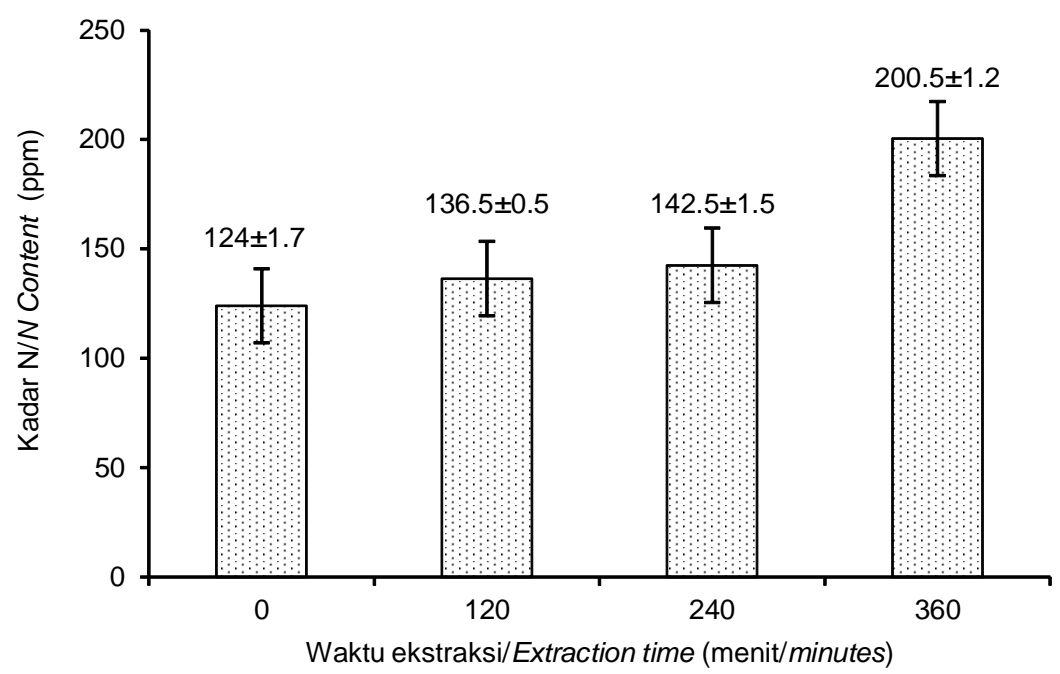

Gambar 7. Nilai N dari cairan proses pengolahan Alkali Treated Sargassum

Figure 7. $N$ value of liquid of Alkali Treated Sargassum 


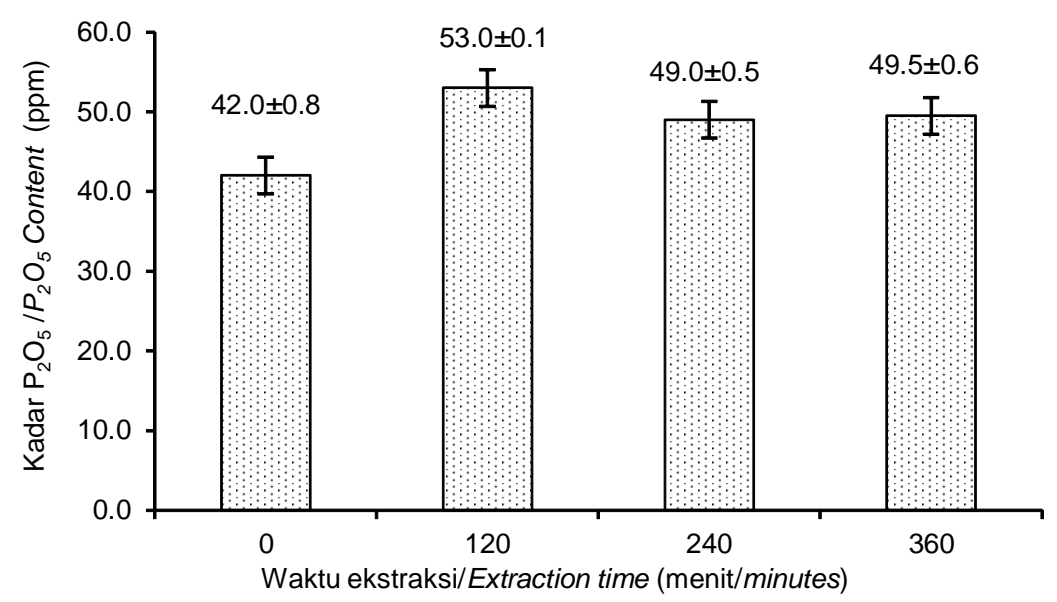

Gambar 8. Kadar $\mathrm{P}_{2} \mathrm{O}_{5}$ dari cairan proses pengolahan Alkali Treated Sargassum

Figure 8. $\mathrm{P}_{2} \mathrm{O}_{5}$ content of liquid of Alkali Treated Sargassum

Hasil penelitian kandungan $\mathrm{K}$ dalam Sargassum adalah sebesar $6,84 \%$. Nilai $\mathrm{K}$ yang dapat diekstrak menggunakan larutan $\mathrm{KOH} 0,1 \%$ pada suhu $80^{\circ} \mathrm{C}$ dengan rentang waktu 0 menit sampai dengan 360 menit ditemukan sangat rendah. Hal ini diduga sejumlah ion $\mathrm{K}^{+}$yang ada dalam talus dan ion $\mathrm{K}^{+}$ hasil disosiasi larutan $\mathrm{KOH}$ telah bereaksi dengan alginat membentuk garam alginat. Diketahui bahwa alginat di dalam talus Sargassum ada dalam bentuk anionik polisakarida yang mudah bereaksi dengan garam ion positif membentuk garam alginat. Basmal et al. (2013) menyebutkan alginat yang ada dalam sel Sargassum bila ditambahkan garam ion akan membentuk polimer alginat/K-alginat. Dalam penelitian ini pelarut yang digunakan adalah larutan
$\mathrm{KOH}$ yang terdisosiasi menjadi ion $\mathrm{K}^{+}$dan $\mathrm{OH}$. Garam ion $\mathrm{K}^{+}$akan bereaksi dengan alginat membentuk polimer alginat (K-alginat). Selanjutnya Basmal et al. (2015) menemukan kandungan K dalam ekstrak cairan Sargassum menggunakan larutan $\mathrm{HCl} 1 \%$ sebesar $345,29 \mathrm{mg} / 100 \mathrm{~g}$ setara dengan $0,35 \%$.

\section{Kadar $\mathbf{C}_{\text {organik }}$}

$\mathrm{C}_{\text {organik }}$ menggambarkan keadaan bahan organik di dalam tanah atau bahan pupuk yang sudah terurai (Sipahutar, Marbun \& Fauzi, 2014). Hasil penelitian menunjukkan nilai $\mathrm{C}_{\text {organik }}$ di dalam cairan Sargassum terekstak berkisar antara $2.000 \pm 0,12$ ppm-3.550 $\pm 0,02$ ppm dengan nlai tertinggi ditemukan pada perlakuan

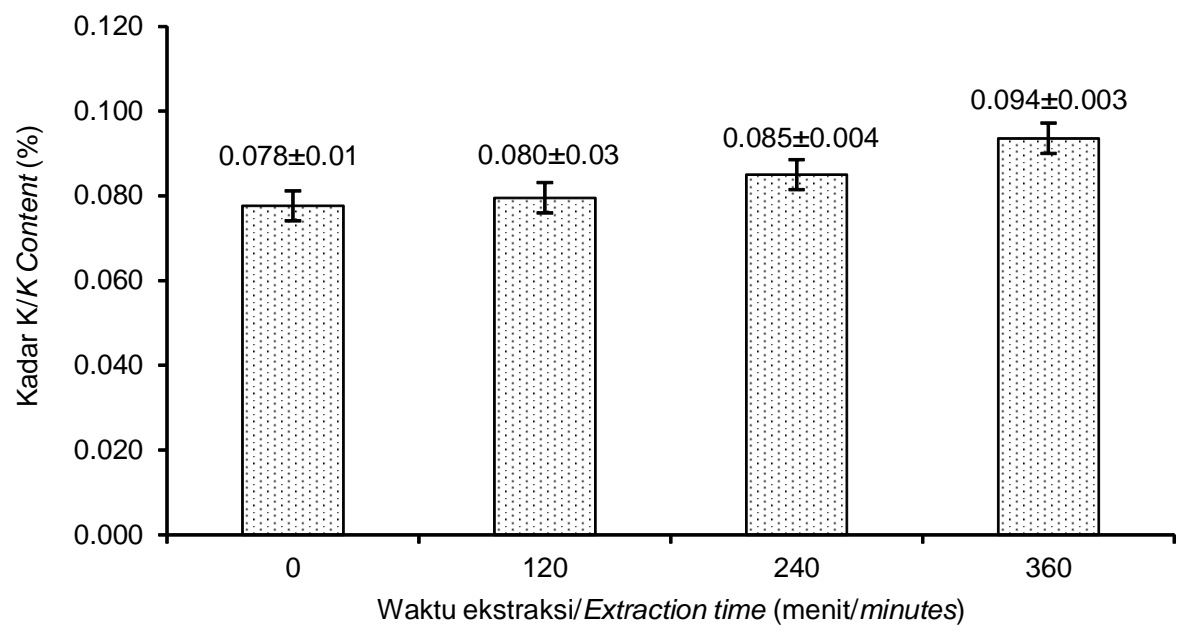

Gambar 9. Nilai Kalium dari cairan proses pengolahan Alkali Treated Sargassum Figure 9. Potassium (K) value of liquid of Alkali Treated Sargassum 


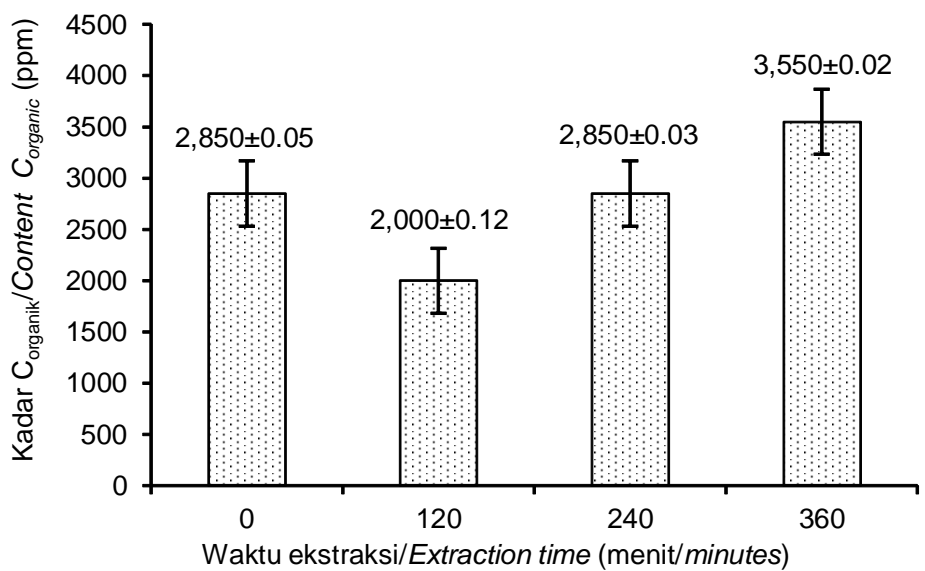

Gambar 10. Nilai $C_{\text {organik }}$ dari cairan proses pengolahan Alkali Treated Sargassum

Figure 10. $C_{\text {organic }}$ value of liquid of Alkali Treated Sargassum

waktu pemasakan 360 menit sebesar $3.550 \pm 0,02$ ppm dan terendah pada perlakuan waktu pemasakan 120 menit sebesar 2.000 $\pm 0,12$ ppm (Gambar 10), sementara perlakuan waktu pemasakan 0 menit dan 240 menit mempunyai nilai $C_{\text {organik }}$ yang sama yakni $2.850 \pm 0,03 \mathrm{ppm}$. Sedangkan dari hasil penelitian yakni Sargassum yang difermentasi telah menghasilkan $C_{\text {organik }}$ sebesar $10,37 \%$ atau setara dengan 103.700 $\mathrm{ppm} . \mathrm{C}_{\text {organik }}$ merupakan kumpulan senyawa-senyawa organik kompleks yang sedang atau telah mengalami proses dekomposisi/pelapukan akibat aktifitas mikroba dan kapang baik berupa humus hasil humifikasi maupun senyawa senyawa anorganik hasil mineralisasi. Rendahnya kadar $\mathrm{C}_{\text {organik }}$ dalam cairan rumput laut terekstrak kemungkinan semua talus Sargassum belum terdekomposisi sempurna. Namun demikian rasio $\mathrm{C} / \mathrm{N}$ berkisar antara 15 - 23. Nilai rasio tertinggi ditemukan pada perlakuan kontrol dengan rasio $\mathrm{C} / \mathrm{N}$ sebesar 23 dan terendah pada perlakuan waktu pemasakan 120 menit $=15$ (Gambar 11). Permentan No 70 tahun 2011 mensyaratkan $\mathrm{C} / \mathrm{N}$ rasio dalam pupuk organik cair minimal 6:1, sedangkan dari hasil penelitian ditemukan nilai rasio terkecil dalam perlakuan ditemukan pada waktu pemasakan 120 menit (Gambar 11) dengan nilai rasio 15:1. Berdasarkan persyaratan Permentan maka semua perlakuan memenuhi syarat yang telah ditetapkan. Gray dan Biddlestone (1973) dan Stewart dan Keith (2006) menyatakan rasio $\mathrm{C} / \mathrm{N}$ dari tanaman laut berkisar antara 4-10:1, sedangkan Ishiwatari dan Uzaki (1987) dan Prahl, Ertel, Goni, Sparrow, dan Eversmeyer (1994) menyatakan rasio $\mathrm{C} / \mathrm{N}$ dari

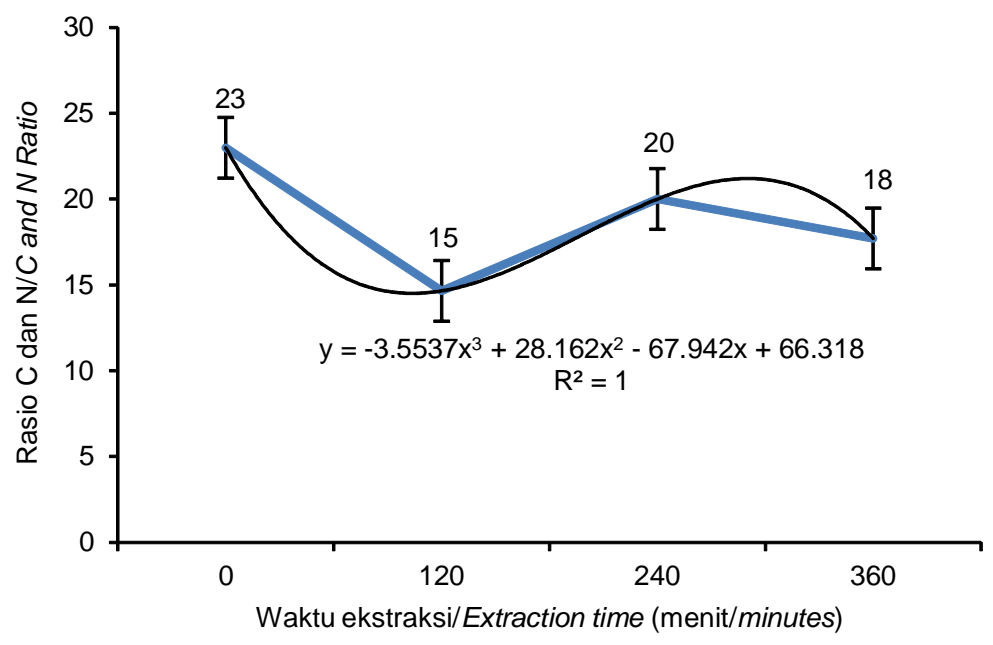

Gambar 11. C/N rasio dari cairan proses pengolahan Alkali Treated Sargassum Figure 11. C/N ratio of liquid of Alkali Treated Sargassum 
tanaman darat lebih besar dari 20:1. Merujuk pada pernyataan di atas maka pemberian perlakuan larutan $\mathrm{KOH} 0,1 \%$ pada suhu $80^{\circ} \mathrm{C}$ dengan rentang waktu 0 360 menit pada pada proses pembuatan Alkali Treated Sargassum dapat menghasilkan rasio $\mathrm{C} / \mathrm{N}$ lebih tinggi. Rasio karbon dan nitrogen yang tinggi akan memacu proses pembungaan dan pembuahan pada tanaman lebih cepat karena merupakan bahan baku pembentukan energi sedangkan nitrogen dibutuhkan dalam pembentukan jaringan. Kelebihan Iain penggunaan rumput laut sebagai bahan baku pupuk organik adanya kandungan protein, lemak, unsur makro dan mikro serta adanya hormon pertumbuhan seperti auksin, sitokinin an giberelin yang dapat merangsang pertumbuhan tanaman (Ishiwatari dan Uzaki (1987), Meyers dan Doose (1999), Muller (1977) dan Sedayu et al. (2013).

\section{KESIMPULAN}

Limbah proses produksi Alkali Treated Sargassum mengandung unsur hara mikro dan makro yang diperlukan untuk formulasi pupuk cair. Hasil penelitian menunjukkan bahwa lama proses pemanasan Sargassum dalam larutan $\mathrm{KOH} 0,1 \%$ pada suhu 80 ${ }^{\circ} \mathrm{C}$ telah mempengaruhi komposisi unsur hara mikro, makro, rendemen, nilai pH dan tingkat kekentalan limbah cair. Secara umum semua limbah dari proses produksi Alkali Treated Sargassum yang telah diperlakukan dapat digunakan sebagai bahan pembuatan pupuk cair. Perlakuan terbaik adalah pemasakan Sargassum dalam larutan $\mathrm{KOH} 0,1 \%$ pada suhu $80^{\circ} \mathrm{C}$ selama 360 menit, dengan limbah cair yang dihasilkan memiliki nilai EC $5,9 \mathrm{mS} / \mathrm{cm}$; TDS $0,46 \%$; pH 7,12; nilai kekentalan 4,64 cPs; kadar N 200,6 ppm; K 0,094 ppm; $\mathrm{C}_{\text {organik }} 3.550$ ppm dan C/N 23.

\section{DAFTAR PUSTAKA}

Anwar, F., Djunaedi, A., \& Santosa, G. (2013). Pengaruh Konsentrasi $\mathrm{KOH}$ yang Berbeda Terhadap Kualitas Alginat Rumput Laut Coklat Sargassum duplicatum J. G. Agardh. Journal Of Marine Research, 2(1), 7-14.

Basmal, J., Yunizal., \& Tazwir. (1998). Pengaruh perlakuan pembuatan semi refined alginat dari rumput laut coklat (Turbinaria ornata) segar terhadap kualitas sodium alginat. Makalah disajikan dalam Forum Komunikasi I. Ikatan Fikologi Indonesia (IFI), 97-110.

Basmal, J. (2010). Liquid organic fertilizer from seaweed (Sargassum sp.) and fish waste hydrolysate.Squalen Bulletin of Marine and Fisheries Postharvest and Biotechnology. 5(2), 59-66

Basmal, J., Kusumawati, R., \& Utomo, B.S.B. (2015). Mutu Sap Liquid Rumput Laut Sargassum Yang
Diekstrak Menggunakan Kalium Hidroksida Sebagai Bahan Pupuk. Jurnal Pascapanen dan Bioteknologi Kelautan dan Perikanan. 10(2), 143-153.

Basmal, J., Utomo, B.S.B., Tazwir., Murdinah., Wikanta, T., Marraskaranto, E., \& Kusumawati, R. (2013). Membuat alginat dari rumput laut Sargassum (pp.92) Jakarta, Indonesia:Penebar Swadaya.

Basmal. J., Kusumawati, R., Nurhayati., \& Hak, N. (2016). Penelitian Pembuatan Pupuk Bio Padat Dan Cair dari Rumput Laut. Laporan Pusat Penelitian dan Pengembangan Daya Saing Produk dan Bioteknologi Kelautanan dan Perikanan.

BSN. (2006). Penentuankadar protein produk perikanan. SNI.01-2354.4-2006.

Burtin, P. (2003). Nutritional value of seaweed. Journal of Agricultural Food Chemistry. 2(4).1-6.

Darmawan, M., Tazwir., \& Hak, N. (2006). Pengaruh Perendaman Rumput Laut Coklat Segar dalam Berbagai Larutan Terhadap Mutu Natrium Alginat. Buletin Teknologi Hasil Perikanan. IX(1), 13.

Gray, K. R., \& Biddlestone, A. J. (1973). Compostingprocess parameters. The Chemical Engineer. 2, 7176.

Handayani, T., Sutarno \& Setyawan. (2004). Analisis Komposisi Nutrisi Rumput Laut Sargassum crassifolium J. Agardh. Biofarmasi. 2(2),45-52.

Husni, A., Subaryono., Pranoto, Y., Tazwir., \& Ustadi. (2012). Pengembangan Metoda Pemasakan Alginat dari Rumput Laut Sargassum sp Sebagai Pengental. Agritech. 32(1),1-8.

Ishiwatari, R., \& Uzaki, M., (1987). Diagenetic Changes of Lignin Compounds in a More Than 0.6 MillionYear-Old Lacustrine Sediment (Lake Biwa, Japan). Geochimica Et Cosmochimica Acta, 51(2), 321-28.

Kirk, R. E., \& Othmer, D. F., (1951). Enclyclopedia of Chemical Technology. The Interscience Encyclopedia Inc., New York. (p. 14).

Latique, S., Chernane, H., Mansori, M., \& El Kaoua, M. (2013). Seaweeds Liquid Fertilizer effect on Physiological and Biochemical Parameters of Bean Plant (Phaesolus vulgaris Paulista) Under Hydroponic System. European Scientific Journal . 9(30), 174-191

Meyers, P. A., \& Doose, H. (1999). Sources, Preservation and Thermal Maturity of Organic Matter in PliocenePlesitonecene Organic-Carbon-Ric Sediment of the Western Mediterranean Sea. Proceedings of the Ocean Drilling Program: Scientific results. 161, 383390.

Muller, P. J. (1977). CN ratios in Pacific deep-sea sediments: Effect of inorganic ammonium and organic nitrogen compounds sorbed by clays. Geochimica et Cosmochimica Acta 41(6), 765-776.

Peraturan Menteri Pertanian (Permentan). (2011). Nomor 70/Permentan/SR. 140/10/2011 tentang Pupuk Organik, Pupuk Hayati dan Pembenah Tanah.

Prahl, F. G., Ertel, J. R., Goni, M. A., Sparrow, M. A., \& Eversmeyer. B. (1994). Terrestrial Organic-Carbon Contributions to Sediments on the Washington 
Margin. Geochimica Et Cosmochimica Acta. 58(14),3035-3048.

Sedayu, B. B., Erawan I. M. S., \& Assadad, L. (2014). Pupuk Cair dari Rumput Laut Eucheuma cottonii, Sargassum sp. dan Gracilaria sp Menggunakan Proses Pengomposan. Jurnal Pascapanen dan Bioteknologi Kelautan dan Perikanan. 9(1), 61-68.

Sedayu, B. B., Basmal, J., \& Utomo, B. S. B. (2013) Identifikasi Hormon Pemacu Tumbuh Esktrak Cair (Sap) Euchema. Jurnal Pascapanen dan Bioteknologi Kelautan dan Perikanan. 8(1), 1-8.

Seswati, R., Nurmiati., \& Priadnadi. (2013). Pengaruh Pengaturan Keasaman Media Serbuk Gergaji Terhadap Pertumbuhan dan Produksi Jamur Tiram Cokelat (Pleurotus cystidiosus O.K. Miller.). Jurnal Biologi Universitas Andalas (J. Bio. UA.). 2(1), 31-36

Sipahutar, A. H., Marbun, P., \& Fauzi. (2014). Kajian Corganik, $\mathrm{N}$ dan $\mathrm{P}$ Humitropepts pada Ketinggian
Tempat yang berbeda di Kecamatan Lintong Nihuta. Jurnal Online argraekoteknologi. 2(4), 1332-1338.

Soeseno, S. (1999). Bisnis Sayur Hidroponik. (pp.1213). Jakarta, Indonesia : PT. Gramedia Pustaka Utama.

Stewart., \& Keith. (2006). It's A Long Road to A Tomato. (pp. 155). New York, USA : New York: Marlowe \& Company.

Sutiyoso. (2003). Meramu Pupuk Hidroponik. (p. 122). Jakarta, Indonesia: Penebar Swadaya.

Yacoba, M. B. (1951), The Chemistry and Technology of Food and Food Products, vol I, Interscience Publishers Inc., New York.

Zailanie, K., Susanto, T., \& Simon B. W. (2001). Pemasakan dan Pemurnian Alginat dari Sargassum filipendula Kajian dari Bagian Tanaman, Lama Pemasakan dan Konsentrasi Isopropanol. Jurnal Teknologi Pertanian. 2 (1),10-27. 
JPB Kelautan dan Perikanan Vol. 12 No. 2 Tahun 2017: 135-147 